Original Research Paper

\title{
Improving Farmers' Income and Soil Environmental Quality through Conservation Agriculture Practice in Bangladesh
}

\author{
${ }^{1}$ Md. Taj Uddin, ${ }^{1}$ Aurup Ratan Dhar and ${ }^{2}$ Md. Hammadur Rahman \\ ${ }^{1}$ Department of Agricultural Economics, Bangladesh Agricultural University, Mymensingh, Bangladesh \\ ${ }^{2}$ Department of Agricultural Extension Education, Bangladesh Agricultural University, Mymensingh, Bangladesh
}

\author{
Article history \\ Received: 04-09-2016 \\ Revised: 22-01-2017 \\ Accepted: 29-03-2017 \\ Corresponding Author: \\ Md. Taj Uddin \\ Department of Agricultural \\ Economics, Bangladesh \\ Agricultural University, \\ Mymensingh, Bangladesh \\ Tel: +88-01714-357803 \\ Email: aurup971@gmail.com
}

\begin{abstract}
The study was accomplished for assessing conservation agriculture practice's impact on farmers' income and soil environmental quality in Bangladesh. Majority of the farmers were within the late majority group in terms of adopting this farming practice. Average annual agricultural income of focal farmers was increased at a higher rate compared to proximal and control farmers after adopting this practice. Most of the focal and proximal farmers stated about improved soil environmental condition where majority of control farmers stated about constant soil environmental condition in this regard. Minimum tillage operation, permanent organic soil cover and application of compost and vermicompost were found significant factors under conservation agriculture affecting soil environmental quality. The problems faced by the farmers included high price of inputs, lack of institutional credit, lack of knowledge about conservation agriculture, etc. Input support, incentive, training programmes and extension services should be well executed by different government and non-government organizations for building consciousness and enhance the knowledge of the farmers on conservation agriculture practice.
\end{abstract}

Keywords: Farmers' Income, Soil Environmental Quality, Conservation Agriculture, Bangladesh

\section{Introduction}

The economy of Bangladesh is mostly dependent on agriculture where above $80 \%$ farmers are smallholder with less than 1.0 hectare cultivable land. The rural economy comprises a noteworthy component of the national GDP with agriculture accounting for $17.2 \%$ (BBS, 2014). As a result of 'Green Revolution', Bangladesh had achieved self adequacy in food production for a shorter period, but long run use of synthetic fertilizers and pesticides resulted in diminished soil fertility and productivity (Kafiluddin and Islam, 2008). In this context, conservation agriculture is fetching increasingly essential in overcoming the problems of waning agricultural productivity in a developing country like Bangladesh. Conservation agriculture can be defined as a concept for resourcesaving agricultural crop production that strives to achieve acceptable profits together with high and sustained production levels while concurrently conserving the environment by following the principles of minimum tillage operation, crop residue management and diversified crop rotations (FAO, 2007). About 8-
$10 \%$ farmers around the world follow this practice although it aspires to help the farmers in earning more money income with reduced amount of lab our, irrigation and other input costs; remain land healthy and productive; and protect natural environment (Lampkin and Padel, 1994; Parrott et al., 2006; Willer et al., 2008).

Environmental problems caused by conventional agricultural practice mainly incorporate infectivity of water and carbon-di-oxide $\left(\mathrm{CO}_{2}\right)$ loss induced from tillage. Practicing conservation agriculture assists agricultural ecosystem to help control agricultural pests; maintain biodiversity; maintain soil fertility; stabilize climatic condition; purify water and air; and normalize disease hauling organisms. Soil, containing high amount of carbon amid organic soil cover and crop residues on the shell are very effectual to boost soil organic content that allows a buffering capacity on soil temperature and improve soil structure and hydraulic conductivity (Reicosky, 2001; West, 2004). Conservation agriculture practice can offset carbon emission through land use and incineration of fossil fuel. This practice is a winwin condition where agriculture wins with better 
production of food and fiber and society wins with the enhanced environmental eminence. Cover crops help to bind the soil elements into aggregates and salvage soil nutrient content that influence the biological community in the soil. Earthworms can increase water penetration, nitrogen availability to plants, soil ventilation and the microbial activity of the soil by feeding off the putrefying fungi, protozoa and bacteria that combine small soil specks altogether into larger aggregates (Clapperton, 2003).

Importance of such farming practice has been portrayed in a good number of literatures. A reticent effort has been made here to appraise the previous research studies which are: Mine et al. (2014) conducted a research on adoption of conservation agriculture in Iowa, Mexico focusing on cover crop use, crop rotations and reduced tillage that can afford many soil conservation benefits and their prospective to contest erosion and nutrient loss and declared them an important tool for protecting water quality. Nguema et al. (2013) studied on conservation agriculture practice's farm-level economic impacts in Ecuador and stated that particular cover crops, crop rotations and reduced amount of tillage intended to reduce soil erosion and increase soil organic matter that can escort to increased farm household income. Lai et al. (2012) accomplished a comparative economic and gender, labor analysis of conservation agriculture in tribal villages inside India and exposed that legume alternation without minimum tillage was more profitable than legume alternation with minimum tillage and it was comparatively more profitable than traditional agriculture. Mazvimavi et al. (2012) executed an analysis on maize productivity and efficiency practicing conservation agriculture in Zimbabwe and showed that $39 \%$ additional output was produced by the farmers following conservation agriculture practice in comparison with conventional agriculture practice. Aune (2012) reviewed the environmental impact of traditional, organic and conservation agriculture and showed that in building soil organic matter with less nitrogen and greenhouse gas emission, conservation agriculture was more efficient than organic farming and conventional agriculture. Jat et al. (2011) discussed the nutrient management perspectives of conservation agriculture in South Asian cereal systems and illustrated that nutrient use, total food grain production and average yield had been increased by $1573 \%, 145 \%$ with an increase in area of just 3.5 and $125 \%$, respectively in India in the last five decades. Roy et al. (2004) focused on conservation tillage's status for small farming in Bangladesh using power tiller operated seeder, zero-till drill with fertilizer distributor and bed former and indicated that these resource conserving technologies had been proved appropriate in many areas of the country.
The above mentioned literatures evidently indicate that most of the studies dealt with conservation agriculture and its economic or environmental aspects but these are not preferably related to the context of Bangladesh. In light of this situation, to curtail the research gap, this study would be supportive at evaluating the consequences of practicing conservation agriculture on farmers' crop profitability as well as their farm income considering soil environmental issues in the circumstance of Bangladesh. The study will identify the determinants of conservation agriculture practice that have significant influence on soil environmental quality. Moreover, the study will address the problems faced by the farmers in practicing conservation agriculture. The specific study objectives are: (i) To assess the impact of conservation agriculture practice on farmers' income and soil environmental quality in relation to conventional agriculture practice; and (ii) to identify the problems faced by the farmers in practicing conservation agriculture.

\section{Materials and Methods}

\section{Selection of the Study Areas}

Five agro-ecological zones of Bangladesh namely Mymensingh (major crop: potato), Bogra (major crop: bean), Tangail (major crop: pineapple), Sherpur (major crop: rice) and Jamalpur (major crop: wheat) were selected to conduct the study.

\section{Selection of Sample and Sampling Technique}

For investigation, three categories of farmers were targeted: focal farmers (farmers who were receiving technical and logistic support from the project and having regular extension contact), proximal farmers (farmers neighboring to focal farmers, receiving technical advice and having occasional extension contact) and control farmers (farmers receiving no training, technical support and extension contact). Following purposive sampling technique, 10 focal farmers and following random sampling technique, 20 proximal and 30 control farmers (i.e., a total of 60 farmers) were selected from each of the study areas. Thus, a total of 300 farmers were included in the study.

\section{Data Sources and Acquisition Methods}

Questionnaire survey, Focus Group Discussion (FGD) and Key Informant Interview (KII) were performed for collecting the primary data. Secondary data sources like reports, publications, handouts, etc. relevant with this study were also checked.

\section{Percentage Perception Index (PPI)}

To evaluate whether there was improvement in soil environmental quality through adopting conservation 
agriculture practices, Percentage Perception Index (PPI) was used. Each farmer of the research areas was asked to indicate his/her option regarding each level of improvement on ten (10) selected opinions. Farmers had option to indicate each as, 'increase', 'decrease' and 'constant' with a corresponding score of 1,2 and 0 , respectively for the statements. To see the percentage of each statement, the following simple percentage formula was used:

$$
P P I=\left[\begin{array}{l}
\text { No. of respondents' opinion about statements } \\
(\text { increase }, \text { decrease or constant }) \times 100
\end{array}\right]
$$

$\div$ Total no. of respondents

\section{Probit Model}

In order to investigate the extent of influence of the factors under conservation agriculture practice on soil environmental quality, probit model was used. The following probit model was used to document the factors' influence level determining soil environmental quality:

$$
\begin{aligned}
& Z_{i}=\Phi^{-1}\left(P_{i}\right)=\beta_{0}+\beta_{1} Q_{1}+\beta_{2} Q_{2} \\
& +\beta_{3} Q_{3}+\beta_{4} Q_{4}+\beta_{5} Q_{5}+\beta_{6} Q_{6}+U_{i}
\end{aligned}
$$

Where:

$\Phi=$ Cumulative distribution function of an explanatory variable $\left[F(Q)=\frac{1}{\sqrt{2 \pi}} \int_{-\infty}^{\beta_{0}+\beta_{i} Q_{i}} e^{\frac{-Z^{2}}{2}} d Z\right]$ that follows normal distribution with mean $\mu$ and variance $\sigma^{2}$

$P_{i} \quad=$ The probability of improving environmental condition or not

$P_{i}=1=$ Indicates improved condition and $P_{i}=0$ indicates otherwise

Dependent variable:

$Z_{i}=$ Improvement in soil environmental quality

Independent variables:

$Q_{1} \quad=$ Minimum tillage operation $\left(P_{i}=1\right.$ indicates practicing minimum tillage and $P_{i}=0$ indicates otherwise)

$Q_{2} \quad=$ Permanent organic soil cover $\left(P_{i}=1\right.$ indicates keeping soil cover and $P_{i}=0$ indicates otherwise)

$Q_{3}=$ Diversified crop rotation (no. of cops per rotation)

$Q_{4} \quad=$ Application of cowdung and bioslurry (kg)

$Q_{5} \quad=$ Application of compost and vermicompost (kg)

$Q_{6} \quad=$ Implementation of IPM technology (gm of pheromone)

$$
\begin{aligned}
\beta_{0} & =\text { Intercept } \\
\beta_{1} \text { to } \beta_{6}= & \text { Regression coefficients of the explanatory } \\
& \text { variables } \\
U_{i}= & \text { Disturbance term }
\end{aligned}
$$

The marginal probabilities of the key determinants of improving soil environmental quality were calculated on the basis of the figures derived from the marginal effect of the probit model was as follows:

$$
d Z / d Q=\beta_{i} \varphi\left[\Phi^{-1}\left(P_{i}\right)\right]
$$

Where:

$\beta_{i}=$ Estimated probit regression coefficient with respect to the $i^{t h}$ factor

$\varphi=$ Standard normal probability distribution function $\left[f(Q)=\frac{1}{\sqrt{2 \pi}} e^{\frac{-Z^{2}}{2}}\right]$

$\Phi=$ Standard normal cumulative distribution function

$P_{i}=$ Estimated probability of soil environmental quality improvement

\section{Problem Confrontation Index (PCI)}

The researcher identified the major problems faced by the farmers in practicing conservation agriculture. An overall score of the problems faced by focal, proximal and control farmers were computed by adding their scores of the problems in all 13 selected problems. Each farmer was asked to indicate the extent of difficulty caused by each of the problems by checking any of the four responses such as 'frequently', 'occasionally', 'rarely' and 'not at all' and weights were assigned to these responses as 3,2,1 and 0 , respectively. The scores of Problem Confrontation Index (PCI) for each selected problem were computed through using the subsequent formula:

$$
\begin{aligned}
& P C I=\left(P_{\text {frequently }} \times 3\right)+\left(P_{\text {occasionally }} \times 2\right) \\
& +\left(P_{\text {rarely }} \times 1\right)+\left(P_{\text {not at all }} \times 0\right)
\end{aligned}
$$

Where:

$P_{\text {frequently }}=$ Number of responses indicating the problem occurred frequently

$P_{\text {occasionally }}=$ Number of responses indicating the problem occurred occasionally

$P_{\text {rarely }}=$ Number of responses indicating the problem occurred rarely

$P_{\text {not at all }}=$ Number of responses indicating no problem at all

The problems were ranked according their PCI score which denoted their severity in practicing conservation agriculture. 


\section{Results and Discussion}

\section{Socioeconomic Characteristics of the Selected Farmers}

The basic information of the farmers is represented in Table 1. It is seen that focal, proximal and control farmers' average household size and average farm size were 5.0, 5.0 and 6.0; and $0.48,0.41$ and 0.52 , respectively. Focal farmers' average dependency ratio (1.4) was relatively lower than proximal and control farmers (1.7 and 3.0, respectively) indicating focal farmers as more self-employed. The percentages of male and female respondents in case of focal, proximal and control farmers were 68.0, 70 and 69.2; and 32.0, 30 and 30.8, respectively.

Average age of focal, proximal and control farmers was 34, 37 and 36 years, respectively. $42.0 \%$ focal farmers could put sign only, but 56.0 and $55.6 \%$ proximal and control farmers, respectively were illiterate in the study areas. Most of the farmers were engaged in farm (i.e., agriculture) as well as non-farm (i.e., labour selling, service, small business, etc.) income generating activities (76.0, 72.0 and $70.8 \%$ focal, proximal and control farmers, respectively). It is also found that the higher portion of the farmers in the study areas were commercial farmers $(82.0 \%$ focal, $71.0 \%$ proximal and $79.0 \%$ control farmers, respectively) (Table 2 ).

\section{Nature of Adopting Conservation Agriculture Practice}

Table 2 shows farmers' nature of adoption of conservation agriculture practice. In the research areas, the farmers of all categories were completely reliant on usage of synthetic fertilizers, pesticides and medicines before adopting conservation agriculture. Focal farmers pursued the fundamental principles of conservation agriculture after adopting conservation agriculture. On the contrary, proximal farmers tried to observe and follow the farming practices of focal farmers, but no conservation agriculture principle was followed by control farmers, rather they continued practicing traditional crop farming. It is experienced that the principles of practicing zero/minimum tillage and retaining crop residue were adopted by focal farmers fully. The selection of apposite crop rotation being an extensive process, it was adopted by them partially. Complete prohibition of using synthetic fertilizers was not possible, but the full usage of organic fertilizers like compost, vermicompost, cowdung and bioslurry and IPM technology; and no usage of pesticides, herbicides and medicines were guaranteed. Retention of crop residue and usage of compost, cowdung and bioslurry were fully adopted by proximal farmers. They also adopted partial use of fertilizers, pesticides and herbicides. Alternatively, no control farmer followed practicing zero/minimum tillage, retaining crop residue and practicing diversified crop rotation. They remained persistent with full usage of chemical fertilizers, pesticides, herbicides and medicines; and partial usage of cowdung and bioslurry (Table 2).

\section{Adopter Categories}

Rogers (1995) defined an adopter category as a classification of individuals within a social system on the basis of innovativeness and suggested a total of five categories of adopters namely, innovators, early adopters, early majority, late majority and laggards in order to standardize the usage of adopter categories in diffusion research. It is evident from Table 3 that in case of adopting an innovation like conservation agriculture, the percentages of innovators were $5.0 \%$, early adopters were $15.0 \%$, early majority were $30.0 \%$, late majority were $35.0 \%$ and laggards were $15.0 \%$. Though majority of the farmers were cynical about this farming practice at the beginning, the adoption of this practice was ultimately successful.

\section{Turnover from Crop Production}

Turnover from crop farming was measured in terms of gross return, net return and marginal rate of return from individual farmer's perspective. Variable and fixed costs were taken into deliberation to estimate the total cost of production. The variable costs included human labour, power tiller, seeds/seedlings, fertilizers, pesticides, medicine, irrigation and fencing; and fixed cost included lease value of land and interest on operating capital. The following formulas were used for calculation:

Gross return $(G R)=Y_{f p} \times P_{f p}$

Where:

$Y_{f p}=$ Yield of final product per unit area

$P_{f p}=$ Price of final product

Net return $(N R)=G R-G C$

Where:

$G R=$ Gross return

$G C=$ Gross cost

Marginal rate of return $(M R R)=M R \div M C$

Where:

$M R=$ Marginal return (i.e., $\mathrm{GR} \div Y_{f p}$ )

$M C=$ Marginal cost (i.e., $\mathrm{GC} \div Y_{f p}$ )

It is evident from Table 4 that total cost incurred by focal, proximal and control farmers was Tk. 
156104, Tk. 155834 and Tk. 156796 per ha, respectively before adopting conservation agriculture which was decreased to Tk. 124834, Tk. 142766 and Tk. 155783 per ha, respectively after adopting conservation agriculture practice. Total cost was decreased by $20.0,8.4$ and $0.6 \%$ for focal, proximal and control farmers, respectively. Though gross return of focal farmers was decreased by $0.6 \%$ (from $\mathrm{Tk}$. 323743 to $\mathrm{Tk}$. 321866) after adopting conservation agriculture; it was increased in case of proximal and control farmers by 6.5 and $10.3 \%$, respectively (from Tk. 300698 to Tk. 320360; and from Tk. 307613 to Tk. 339279, respectively).

Net return of focal, proximal and control farmers was Tk. 167638, Tk. 144864 and Tk. 150817, respectively before adopting conservation agriculture practice; and it was increased to Tk. 197032, Tk. 177594 and Tk. 183496, respectively after adopting conservation agriculture indicating an increase in net return by $17.5,22.6$ and $21.7 \%$, respectively.

Table 1. Basic information about the selected farmers (in average)

\begin{tabular}{|c|c|c|c|c|}
\hline \multirow[b]{2}{*}{ Particulars } & & \multicolumn{3}{|c|}{ Farmers' categories } \\
\hline & & Focal & Proximal & Control \\
\hline Household size (no.) & & 5.00 & 5.00 & 6.00 \\
\hline Farm size (ha) & & 0.48 & 0.41 & 0.52 \\
\hline Dependency ratio (no.) & & 1.40 & 1.70 & 3.00 \\
\hline \multirow[t]{2}{*}{ Sex distribution ( $\%$ of farmers) } & Male & 68.0 & 70.0 & 69.2 \\
\hline & Female & 32.0 & 30.0 & 30.8 \\
\hline Age (years) & & 34.0 & 37.0 & 36.0 \\
\hline \multirow[t]{3}{*}{ Literacy rate (\% of farmers) } & Illiterate & 32.0 & 56.0 & 55.6 \\
\hline & Sign only & 42.0 & 27.0 & 22.4 \\
\hline & Primary and above & 26.0 & 17.0 & 22.0 \\
\hline \multirow[t]{2}{*}{ Occupational status ( $\%$ of farmers) } & Agriculture only & 24.0 & 28.0 & 29.2 \\
\hline & Agriculture and others & 76.0 & 72.0 & 70.8 \\
\hline Farming systems practiced & Subsistence & 18.0 & 29.0 & 21.0 \\
\hline (\% of farmers) & Commercial & 82.0 & 71.0 & 79.0 \\
\hline
\end{tabular}

Table 2. Farmers' nature of adoption of conservation agriculture practice

\begin{tabular}{|c|c|c|c|}
\hline \multirow[b]{2}{*}{ Particulars } & \multicolumn{3}{|c|}{ Farmers' categories } \\
\hline & Focal & Proximal & Control \\
\hline Practicing zero/minimum tillage & $\sqrt{\mathrm{a}}$ & $x^{c}$ & $x^{c}$ \\
\hline Retaining crop residue & $\sqrt{\mathrm{a}}$ & $\sqrt{\mathrm{a}}$ & $x^{c}$ \\
\hline Practicing crop rotation & $\mathbf{w}^{\mathrm{b}}$ & $x^{c}$ & $x^{c}$ \\
\hline Using synthetic fertilizers & $\mathbf{w}^{\mathrm{b}}$ & $\mathrm{w}^{\mathrm{b}}$ & $\sqrt{\mathrm{a}}$ \\
\hline Using synthetic pesticides & $x^{c}$ & $\mathrm{w}^{\mathrm{b}}$ & $\sqrt{\mathrm{a}}$ \\
\hline Using herbicides & $x^{c}$ & $\mathrm{~m}^{\mathrm{b}}$ & $\sqrt{\mathrm{a}}$ \\
\hline Using medicine & $x^{c}$ & $x^{c}$ & $\sqrt{\mathrm{a}}$ \\
\hline Using compost & $\sqrt{\mathrm{a}}$ & $\sqrt{\mathrm{a}}$ & $x^{c}$ \\
\hline Using vermicompost & $\sqrt{\mathrm{a}}$ & $x^{c}$ & $x^{c}$ \\
\hline Using cowdung & $\sqrt{a}$ & $\sqrt{a}$ & $\mathbb{m}^{\mathrm{b}}$ \\
\hline Using bioslurry & $\sqrt{\mathrm{a}}$ & $\sqrt{\mathrm{a}}$ & $\nabla^{\mathrm{b}}$ \\
\hline Using IPM technology & $\sqrt{\mathrm{a}}$ & $x^{c}$ & $x^{c}$ \\
\hline \multicolumn{4}{|l|}{$\begin{array}{l}\text { a. } \sqrt{\text { indicates full adoption }} \\
\text { b. } \text { w indicates partial adoption } \\
\text { c. } \times \text { indicates no adoption. }\end{array}$} \\
\hline \multicolumn{4}{|c|}{$\begin{array}{ll}\text { Trend of adoption } & \text { Trend }\end{array}$} \\
\hline Adopter categories & \multicolumn{2}{|c|}{ No. of farmers $\left(\mathrm{N}^{\mathrm{a}}=50\right)$} & Percentage of farmers \\
\hline Innovators & \multicolumn{2}{|c|}{3} & 5.0 \\
\hline Early adopters & \multicolumn{2}{|c|}{8} & 15.0 \\
\hline Early majority & \multicolumn{2}{|c|}{14} & 30.0 \\
\hline Late majority & \multicolumn{2}{|c|}{17} & 35.0 \\
\hline Laggards & \multicolumn{2}{|c|}{8} & 15.0 \\
\hline
\end{tabular}

a. $\mathrm{N}$ indicates number of farmers 
Table 4. Turnover from crop production in the study areas

\begin{tabular}{|c|c|c|c|c|c|c|}
\hline \multirow[b]{3}{*}{ Particulars } & \multicolumn{6}{|c|}{ Farmers' categories } \\
\hline & \multicolumn{2}{|l|}{ Focal } & \multicolumn{2}{|c|}{ Proximal } & \multicolumn{2}{|l|}{ Control } \\
\hline & Before & After & Before & After & Before & After \\
\hline Total output (quintal/ha) & 141.5 & 142.2 & 140.3 & 141.8 & 140.3 & 142.2 \\
\hline Price (Tk./quintal) & 2288 & 2263 & 2143 & 2259 & 2193 & 2386 \\
\hline Total cost (TC) (Tk./ha) & 156104 & 124834 & 155834 & 142766 & 156796 & 155783 \\
\hline Change in TC $(\%)$ & -20.0 & & -8.4 & & -0.6 & \\
\hline Gross return (GR) (Tk./ha) & 323743 & 321866 & 300698 & 320360 & 307613 & 339279 \\
\hline Change in GR $(\%)$ & -0.6 & & 6.5 & & 10.3 & \\
\hline Net return (NR) (Tk./ha) & 167638 & 197032 & 144864 & 177594 & 150817 & 183496 \\
\hline Change in NR (\%) & 17.5 & & 22.6 & & 21.7 & \\
\hline Marginal cost (Tk./quintal) & 1103 & 878 & 1111 & 1007 & 1118 & 1096 \\
\hline Marginal return (Tk./quintal) & 2288 & 2263 & 2143 & 2259 & 2193 & 2386 \\
\hline Marginal rate of return (MRR) & 2.07 & 2.58 & 1.93 & 2.24 & 1.96 & 2.18 \\
\hline Change in MRR (\%) & 24.3 & & 16.3 & & 11.0 & \\
\hline
\end{tabular}

Table 5. Average annual agricultural income of the farmers

\begin{tabular}{|c|c|c|c|c|c|c|c|c|c|}
\hline \multirow[b]{3}{*}{$\begin{array}{l}\text { Sources } \\
\text { of income }\end{array}$} & \multicolumn{9}{|c|}{ Farmers' categories } \\
\hline & \multicolumn{3}{|l|}{ Focal } & \multicolumn{3}{|c|}{ Proximal } & \multicolumn{3}{|l|}{ Control } \\
\hline & $\begin{array}{l}\text { Before } \\
\text { (Tk.) }\end{array}$ & $\begin{array}{l}\text { After } \\
\text { (Tk.) }\end{array}$ & $\begin{array}{l}\text { Change } \\
(\%)\end{array}$ & $\begin{array}{l}\text { Before } \\
\text { (Tk.) }\end{array}$ & $\begin{array}{l}\text { After } \\
\text { (Tk.) }\end{array}$ & $\begin{array}{l}\text { Change } \\
(\%)\end{array}$ & $\begin{array}{l}\text { Before } \\
\text { (Tk.) }\end{array}$ & $\begin{array}{l}\text { After } \\
\text { (Tk.) }\end{array}$ & $\begin{array}{l}\text { Change } \\
(\%)\end{array}$ \\
\hline Rice & 27985 & 30279 & 8.2 & 28295 & 30138 & 6.5 & 28855 & 30127 & 4.4 \\
\hline Vegetables & 33267 & 36754 & 10.5 & 32664 & 34519 & 5.7 & 32419 & 34972 & 7.9 \\
\hline Fruits & 8617 & 9099 & 5.6 & 8801 & 9100 & 3.4 & 8325 & 8514 & 2.3 \\
\hline Agroforestry & 1549 & 1970 & 27.2 & 1805 & 1946 & 7.8 & 2000 & 2045 & 2.3 \\
\hline Livestock & 8037 & 9112 & 13.4 & 8779 & 9473 & 7.9 & 9027 & 9672 & 7.1 \\
\hline Fisheries & 750 & 820 & 9.3 & 695 & 866 & 24.6 & 754 & 910 & 20.7 \\
\hline Others & 1846 & 2065 & 11.9 & 1955 & 2459 & 25.8 & 1885 & 2249 & 19.3 \\
\hline Total & 82051 & 90099 & 9.8 & 82994 & 88501 & 6.6 & 83265 & 88489 & 6.3 \\
\hline
\end{tabular}

Table 6. Farmers' perceptions regarding the impact of conservation agriculture practice on soil environmental quality

\begin{tabular}{|c|c|c|c|c|c|c|c|c|c|}
\hline \multirow[b]{3}{*}{ Statements } & \multicolumn{9}{|c|}{ Farmers' categories } \\
\hline & \multicolumn{3}{|c|}{ Focal $(\mathrm{N}=50)^{\mathrm{a}}$} & \multicolumn{3}{|c|}{ Proximal $(\mathrm{N}=100)^{\mathrm{a}}$} & \multicolumn{3}{|c|}{ Control $(\mathrm{N}=150)^{\mathrm{a}}$} \\
\hline & Increase & Decrease & Constant & Increase & Decrease & Constant & Increase & Decrease & Constant \\
\hline Soil organic matter content & $\begin{array}{l}37 \\
(74.0)^{\mathrm{b}}\end{array}$ & $\begin{array}{l}3 \\
(6.0)^{b}\end{array}$ & $\begin{array}{l}10 \\
(20.0)^{\mathrm{b}}\end{array}$ & $\begin{array}{l}36 \\
(36.0)^{b}\end{array}$ & $\begin{array}{l}22 \\
(22.0)^{\mathrm{b}}\end{array}$ & $\begin{array}{l}42 \\
(42.0)^{\mathrm{b}}\end{array}$ & $\begin{array}{l}28 \\
(18.7)^{b}\end{array}$ & $\begin{array}{l}53 \\
(35.3)^{\mathrm{b}}\end{array}$ & $\begin{array}{l}69 \\
(46.0)^{b}\end{array}$ \\
\hline Soil water holding capacity & $\begin{array}{l}31 \\
(62.0)^{b}\end{array}$ & $\begin{array}{l}6 \\
(12.0)^{b}\end{array}$ & $\begin{array}{l}13 \\
(26.0)^{b}\end{array}$ & $\begin{array}{l}45 \\
(45.0)^{\mathrm{b}}\end{array}$ & $\begin{array}{l}25 \\
(25.0)^{b}\end{array}$ & $\begin{array}{l}30 \\
(30.0)^{b}\end{array}$ & $\begin{array}{l}60 \\
(40.0)^{b}\end{array}$ & $\begin{array}{l}18 \\
(12.0)^{b}\end{array}$ & $\begin{array}{l}72 \\
(48.0)^{b}\end{array}$ \\
\hline Soil fertility & $\begin{array}{l}29 \\
(58.0)^{\mathrm{b}}\end{array}$ & $\begin{array}{l}8 \\
(16.0)^{b}\end{array}$ & $\begin{array}{l}13 \\
(26.0)^{b}\end{array}$ & $\begin{array}{l}38 \\
(38.0)^{\mathrm{b}}\end{array}$ & $\begin{array}{l}20 \\
(20.0)^{\mathrm{b}}\end{array}$ & $(42.0)^{\mathrm{b}}$ & $\begin{array}{l}48 \\
(32.0)^{\mathrm{b}}\end{array}$ & $\begin{array}{l}40 \\
(26.7)^{b}\end{array}$ & $\begin{array}{l}62 \\
(41.3)^{b}\end{array}$ \\
\hline Soil nutrient availability & $\begin{array}{l}33 \\
(66.0)^{\mathrm{b}}\end{array}$ & $\begin{array}{l}3 \\
(6.0)^{b}\end{array}$ & $\begin{array}{l}14 \\
(28.0)^{\mathrm{b}}\end{array}$ & $\begin{array}{l}49 \\
(49.0)^{b}\end{array}$ & $\begin{array}{l}25 \\
(25.0)^{\mathrm{b}}\end{array}$ & $\begin{array}{l}26 \\
(26.0)^{b}\end{array}$ & $\begin{array}{l}48 \\
(32.0)^{\mathrm{b}}\end{array}$ & $\begin{array}{l}37 \\
(24.7)^{\mathrm{b}}\end{array}$ & $\begin{array}{l}65 \\
(43.3)^{b}\end{array}$ \\
\hline Soil sediment content & $\begin{array}{l}28 \\
(56.0)^{\mathrm{b}}\end{array}$ & $\begin{array}{l}6 \\
(12.0)^{b}\end{array}$ & $\begin{array}{l}16 \\
(32.0)^{\mathrm{b}}\end{array}$ & $\begin{array}{l}36 \\
(36.0)^{\mathrm{b}}\end{array}$ & $(38.0)^{\mathrm{b}}$ & $\begin{array}{l}26 \\
(26.0)^{b}\end{array}$ & $\begin{array}{l}49 \\
(32.7)^{b}\end{array}$ & $\begin{array}{l}21 \\
(14.0)^{\mathrm{b}}\end{array}$ & $\begin{array}{l}80 \\
(53.3)^{\mathrm{b}}\end{array}$ \\
\hline Soil compaction & $\begin{array}{l}39 \\
(78.0)^{\mathrm{b}}\end{array}$ & $\begin{array}{l}2 \\
(4.0)^{b}\end{array}$ & $(18.0)^{\mathrm{b}}$ & $\begin{array}{l}51 \\
(51.0)^{\mathrm{b}}\end{array}$ & $\begin{array}{l}16 \\
(16.0)^{\mathrm{b}}\end{array}$ & $(33.0)^{\mathrm{b}}$ & $\begin{array}{l}31 \\
(20.7)^{b}\end{array}$ & $\begin{array}{l}58 \\
(38.7)^{\mathrm{b}}\end{array}$ & $\begin{array}{l}61 \\
(40.7)^{b}\end{array}$ \\
\hline Soil erosion & $(8.0)^{\mathrm{b}}$ & $\begin{array}{l}26 \\
(52.0)^{\mathrm{b}}\end{array}$ & $\begin{array}{l}20 \\
(40.0)^{\mathrm{b}}\end{array}$ & $(13.0)^{\mathrm{b}}$ & $\begin{array}{l}45 \\
(45.0)^{\mathrm{b}}\end{array}$ & $\begin{array}{l}42 \\
(42.0)^{b}\end{array}$ & $\begin{array}{l}66 \\
(44.0)^{b}\end{array}$ & $\begin{array}{l}34 \\
(22.7)^{b}\end{array}$ & $\begin{array}{l}50 \\
(33.3)^{\mathrm{b}}\end{array}$ \\
\hline $\begin{array}{l}\text { Quality of nearby } \\
\text { water resources }\end{array}$ & $\begin{array}{l}32 \\
(64.0)^{\mathrm{b}}\end{array}$ & $\begin{array}{l}5 \\
(10.0)^{b}\end{array}$ & $\begin{array}{l}13 \\
(26.0)^{b}\end{array}$ & $\begin{array}{l}37 \\
(37.0)^{\mathrm{b}}\end{array}$ & $\begin{array}{l}35 \\
(35.0)^{\mathrm{b}}\end{array}$ & $\begin{array}{l}28 \\
(28.0)^{\mathrm{b}}\end{array}$ & $\begin{array}{l}36 \\
(24.0)^{\mathrm{b}}\end{array}$ & $\begin{array}{l}63 \\
(42.0)^{\mathrm{b}}\end{array}$ & $\begin{array}{l}51 \\
(34.0)^{\mathrm{b}}\end{array}$ \\
\hline Air quality & $\begin{array}{l}29 \\
(58.0)^{\mathrm{b}}\end{array}$ & $(18.0)^{\mathrm{b}}$ & $\begin{array}{l}12 \\
(24.0)^{\mathrm{b}}\end{array}$ & $\begin{array}{l}40 \\
(40.0)^{b}\end{array}$ & 32 (32.0) & $\begin{array}{l}28 \\
(28.0)^{\mathrm{b}}\end{array}$ & $\begin{array}{l}41 \\
(27.3)^{b}\end{array}$ & $\begin{array}{l}57 \\
(38.0)^{\mathrm{b}}\end{array}$ & $\begin{array}{l}52 \\
(34.7)^{b}\end{array}$ \\
\hline $\begin{array}{l}\text { Biodiversity of } \\
\text { agrarian medium }\end{array}$ & $\begin{array}{l}28 \\
(56.0)^{\mathrm{b}}\end{array}$ & $\begin{array}{l}10 \\
(20.0)^{\mathrm{b}}\end{array}$ & $\begin{array}{l}12 \\
(24.0)^{\mathrm{b}}\end{array}$ & $\begin{array}{l}53 \\
(53.0)^{\mathrm{b}}\end{array}$ & $\begin{array}{l}28 \\
(28.0)^{\mathrm{b}}\end{array}$ & $\begin{array}{l}19 \\
(19.0)^{\mathrm{b}}\end{array}$ & $\begin{array}{l}53 \\
(35.3)^{\mathrm{b}}\end{array}$ & $\begin{array}{l}33 \\
(22.0)^{\mathrm{b}}\end{array}$ & $\begin{array}{l}64 \\
(42.7)^{b}\end{array}$ \\
\hline $\begin{array}{l}\text { Average perception on } \\
\text { soil environmental quality }\end{array}$ & $\begin{array}{l}29 \\
(58.0)^{\mathrm{b}}\end{array}$ & 8 & $\begin{array}{l}13 \\
(26.0)^{\mathrm{b}}\end{array}$ & $\begin{array}{l}40 \\
(40.0)^{\mathrm{b}}\end{array}$ & $\begin{array}{l}28 \\
(28.0)^{\mathrm{b}}\end{array}$ & $\begin{array}{l}32 \\
(32.0)^{\mathrm{b}}\end{array}$ & $\begin{array}{l}46 \\
(30.7)^{b}\end{array}$ & $\begin{array}{l}41 \\
(27.3)^{\mathrm{b}}\end{array}$ & $(42.0)^{\mathrm{b}}$ \\
\hline
\end{tabular}

a. $\mathrm{N}$ indicates number of farmers; and

b. Figures within parentheses indicate percentages of farmers. 
Table 4 also depicts that after adopting conservation agriculture practice, marginal rate of return of focal, proximal and control farmers was increased to 2.58, 2.24 and 2.18 from $2.07,1.93$ and 1.96 by $24.3,16.3$ and $11.0 \%$, respectively. Low input employment cost and higher consumer magnetism to organic products were the major reasons of focal farmers' being more profitable compared to proximal and control farmers.

\section{Average Annual Agricultural Income of the Sample Farmers}

Table 5 represents the money income earned by the farmers in the study areas from different agricultural sources like crop (rice, vegetables, etc.), livestock (large animal i.e., cow, ox, bullock, buffalo, goat, sheep, etc.; and small animal i.e., poultry, duck, pigeon, etc.), fishery, agroforestry and others. It is apparent that average annual farm income of focal, proximal and control farmers was increased by $9.8,6.6$ and $6.3 \%$, respectively. The results entail that farmers earned $\mathrm{Tk}$. 100 money income from agricultural sources before practicing conservation agriculture while after practicing conservation agriculture, focal, proximal and control farmers earned about Tk. 110, Tk. 107 and Tk. 106 money income, respectively. This findings is faintly similar with the result of Uddin and Fatema (2016) where the authors found that management of rice crop residue had a significant impact on crop productivity, profitability and annual income of the farm households.

\section{Farmers' Perceptions about Impact of Conservation Agriculture Practice on Soil Environmental Quality}

To appraise the impact of adopting conservation agriculture on soil environmental quality, the researchers made discussion with the farmers of the study areas before and after adopting such farming practice. After the discussion, ten (10) opinions were selected for the research. Each farmer was asked to indicate his/her opinion regarding the level of improvement.

The number of farmers sharing their opinions on the selected statements and their percentages are represented in Table 6. It is revealed that majority of both focal and proximal farmers stated about improved soil environmental condition after adopting conservation agriculture than before, while majority of control farmers stated about constant soil environmental condition in this regard.

Table 6 depicts that after adopting conservation agriculture, focal farmers experienced increase in soil organic matter content $(74.0 \%)$, soil water holding capacity $(62.0 \%)$, soil fertility $(58.0 \%)$, soil nutrient availability $(66.0 \%)$, soil sediment content $(56.0 \%)$, soil compaction $(78.0 \%)$, quality of nearby water resources $(64.0 \%)$, air quality $(58.0 \%)$ and biodiversity of agrarian medium (56.0\%); and decrease in soil erosion (52.0\%).
According to proximal farmers, they experienced increase in soil water holding capacity $(45.0 \%)$, soil nutrient availability (49.0\%), soil compaction (51.0\%), quality of nearby water resources $(37.0 \%)$, air quality $(40.0 \%)$ and biodiversity of agrarian medium (53.0\%); but decrease in soil organic matter content $(42.0 \%)$ and soil fertility $(42.0 \%)$ with a constant state of soil sediment content $(38.0 \%)$ and soil erosion (45.0\%). On the other hand, 46.0, 48.0, 41.3, 43.3, 53.3, 40.7 and $42.7 \%$ control farmers observed no change in soil organic matter content, soil water holding capacity, soil fertility, soil nutrient availability, soil sediment content, soil compaction and biodiversity of agrarian medium, respectively; but they observed increased soil erosion $(44.0 \%)$ and decreased quality of nearby water resources $(42.0 \%)$ and air quality $(38.0 \%)$ while practicing conventional farming system. Overall, 58.0, 16.0 and $26.0 \%$ focal farmers; $40.0,28.0$ and $32.0 \%$ proximal farmers; and 30.7.0, 27.3.0 and 42.0\% control farmers in the study areas assured about increased, decreased and constant soil environmental quality, respectively after adopting conservation agriculture practice (Table 5). This result is partly similar with Palm et al. (2014) where the authors overviewed on conservation agriculture and ecosystem services and revealed that conservation agriculture changes soil properties and processes which can affect the delivery of ecosystem services, including climate regulation through carbon sequestration and greenhouse gas emissions and regulation and provision of water through soil physical, chemical and biological properties.

Factors Influencing Improvement in Soil Environmental Quality under Conservation Agriculture Practice

A probit model was used conveying the determinants influencing improvement in soil environmental quality under conservation agriculture practice. Six explanatory variables were identified as major factors for this study. Three out of six explanatory variables included in the model were found significant in explaining the variation in improving soil environmental quality. These variables were minimum soil tillage operation, permanent organic soil cover and application of compost and vermicompost (Table 7).

Therefore the estimated equation was as follows:

$$
\begin{aligned}
& Z_{i}=1.286+0.011 Q_{1}+0.026 Q_{2} \\
& -0.182 Q_{3}+0.002 Q_{4}+0.003 Q_{5}-0.002 Q_{6}
\end{aligned}
$$

Marginal effect was calculated separately for categorical and continuous variables. It measured distinct change i.e., how expected probabilities were altered as the binary explanatory variable changed from 0 to 1 . Marginal effects for continuous variables measured the instantaneous rate of change (Table 8). 
Table 7. Estimates of probit model of factors influencing improvement in soil environmental quality

\begin{tabular}{|c|c|c|c|c|c|c|}
\hline Variables & $\begin{array}{l}\text { Coefficient } \\
(\beta)\end{array}$ & $\begin{array}{l}\text { Standard } \\
\text { error }\end{array}$ & $\mathrm{z}$ & $\mathrm{P}>|\mathrm{z}|$ & \multicolumn{2}{|c|}{$95 \%$ confidence interval } \\
\hline Constant & 1.286 & 0.751 & 1.71 & 0.387 & -0.184 & 2.758 \\
\hline Minimum tillage operation $\left(Q_{1}\right)$ & 0.011 & 0.011 & 1.08 & 0.042 & -0.032 & -0.009 \\
\hline Permanent organic soil cover $\left(Q_{2}\right)$ & 0.026 & 0.278 & 0.91 & $0.047 * *^{\mathrm{a}}$ & -0.080 & -0.029 \\
\hline Diversified crop rotation $\left(Q_{3}\right)$ & -0.182 & 0.106 & -1.73 & 0.384 & -0.025 & 0.389 \\
\hline Application of cowdung and bioslurry $\left(Q_{4}\right)$ & 0.002 & 0.001 & 2.67 & $0.077 * \mathrm{~b}$ & 0.004 & -0.001 \\
\hline Application of compost and vermicompost $\left(Q_{5}\right)$ & 0.003 & 0.001 & 2.48 & $0.093 * \mathrm{~b}$ & 0.001 & 0.005 \\
\hline Implementation of IPM technology $\left(Q_{6}\right)$ & -0.002 & 0.001 & -2.83 & 0.175 & -0.003 & 0.000 \\
\hline
\end{tabular}

a. $* *$ indicates significant at $5 \%$ probability level

b. * indicates significant at $10 \%$ probability level

Table 8. Estimates of marginal effect of factors influencing improvement in soil environmental quality

\begin{tabular}{|c|c|c|c|c|c|c|c|}
\hline \multirow{3}{*}{$\frac{\text { Variables }}{\text { Minimum tillage operation }\left(\mathrm{Q}_{1}\right)}$} & \multirow{3}{*}{$\frac{\mathrm{dZ} / \mathrm{dQ}}{0.004}$} & \multirow{3}{*}{$\begin{array}{l}\text { Standard } \\
\text { Error } \\
0.004\end{array}$} & \multirow{3}{*}{$\begin{array}{l}\mathrm{z} \\
1.08\end{array}$} & \multirow{3}{*}{$\frac{\mathrm{P}>|\mathrm{z}|}{0.213}$} & \multirow{2}{*}{\multicolumn{2}{|c|}{$\begin{array}{l}95 \% \text { confidence } \\
\text { interval }\end{array}$}} & \multirow{3}{*}{$\begin{array}{l}\text { Q } \\
38.240\end{array}$} \\
\hline & & & & & & & \\
\hline & & & & & -0.012 & -0.003 & \\
\hline Permanent organic soil cover $\left(\mathrm{Q}_{2}\right)$ & 0.010 & 0.011 & 0.91 & $0.031 * * a$ & -0.030 & -0.011 & 9.040 \\
\hline Diversified crop rotation $\left(\mathrm{Q}_{3}\right)$ & -0.069 & 0.040 & -1.72 & 0.485 & 0.010 & 0.147 & 0.949 \\
\hline Application of cowdung and bioslurry $\left(\mathrm{Q}_{4}\right)$ & 0.001 & 0.000 & 2.69 & $0.087 * \mathrm{~b}$ & -0.001 & -0.000 & 394.700 \\
\hline Application of compost and vermicompost $\left(\mathrm{Q}_{5}\right)$ & 0.001 & 0.000 & 2.49 & $0.061 * b$ & 0.000 & 0.002 & 294.313 \\
\hline Implementation of IPM technology $\left(Q_{6}\right)$ & -0.001 & 0.000 & -2.85 & 0.114 & -0.001 & 0.000 & 763.707 \\
\hline
\end{tabular}

a. $* *$ indicates significant at $5 \%$ probability level

b. * indicates significant at $10 \%$ probability level

The result of marginal effect shows that minimum tillage operation had a positive value of $\mathrm{dZ} / \mathrm{dQ}$ and it was 0.004 . It meant that the probability of improving soil environmental quality is 0.004 times higher for practicing minimum-till farming compared to for not practicing it (Table 8).

Keeping permanent organic soil cover (i.e., crop residue) had a positive value of $\mathrm{dZ} / \mathrm{dQ}$ which was 0.010 and it was statistically significant at $5 \%$ probability level. It meant that for keeping crop residue in the crop field, the probability of improvement in soil environmental quality is 0.010 times higher than for not keeping crop residue. This reason was that keeping crop residue in the field helped to manage soil nutrient balance or cycling it and reduce emission of soil particulars.

The result of marginal effect shows that following diversified crop rotation had a negative value of $\mathrm{dZ} / \mathrm{dQ}$ and it was 0.069 . It indicated that if crop rotation is increased by 1 unit, the probability of improving soil environmental quality will decrease by 0.069 times (Table 8 ).

The result of marginal effect shows that application of cowdung and bioslurry had a positive value of $\mathrm{dZ} / \mathrm{dQ}$ and it was 0.001 , which was statistically significant at $10 \%$ level of probability. It demonstrated that if cowdung and bioslurry application is increased by 1 unit, the probability of improvement in soil environmental quality will increase by 0.001 times. The reason was that applying cowdung and bioslurry in the field helped to provide soil nutrient and improve soil health.

Application of compost and vermicompost had a positive value of $\mathrm{dZ} / \mathrm{dQ}$ which was 0.001 and it was statistically significant at $10 \%$ probability level. It indicated that if compost and vermicompost application is increased by 1 unit, the probability of improving soil environmental quality will increase by 0.001 times. The reason was that application of compost and vermicompost is very complimentary for amplifying water infiltration, soil aeration, soil microbial activity and nitrogen availability to the plants.

Implementation of IPM technology for pest control had a negative value of $\mathrm{dZ} / \mathrm{dQ}$ and it was 0.001 . It implied that if the implementation of IPM technology is increased by 1 unit, the probability of improving soil environmental quality will decrease by 0.001 times.

\section{Problem Confrontation Index (PCI)}

Problem Confrontation Index (PCI) is a mathematically problem ranking index which is defined as a set of objects whose state must satisfy a number of problems or limitations. It represents the entities in a problem as a homogeneous collection of finite limitations over variables in a specific area. The farmers of the study areas were asked to give their opinion on 13 selected problems which were identified during data collection period and after computing the PCI scores, the problems were ranked according to their PCI score. The computed PCI score of the 13 problems ranged from 113 to 136 (against a possible range from 0 to 150) for focal farmers, 204 to 261 (against a possible range from 0 to 300 ) for proximal farmers and 314 to 388 (against a possible range from 0 to 300) for control farmers which were arranged in rank order according to their PCI scores as shown in Table 9. 
Table 9. Problem confrontation index including thirteen (13) selected problems

\begin{tabular}{|c|c|c|c|c|c|c|c|c|c|c|c|c|c|c|c|c|c|c|}
\hline \multirow[b]{3}{*}{ Problems identified } & \multicolumn{18}{|c|}{ Farmers' categories } \\
\hline & \multicolumn{6}{|c|}{ Focal $(\mathrm{N}=50)^{\mathrm{a}}$} & \multicolumn{6}{|c|}{ Proximal $(\mathrm{N}=100)^{\mathrm{a}}$} & \multicolumn{6}{|c|}{ Control $(\mathrm{N}=150)^{\mathrm{a}}$} \\
\hline & $\begin{array}{l}\text { Frequently } \\
\text { (3) }\end{array}$ & $\begin{array}{l}\text { Occasionally } \\
\text { (2) }\end{array}$ & $\begin{array}{l}\text { y Rarely } \\
\text { (1) }\end{array}$ & $\begin{array}{l}\text { Not at } \\
\text { all }(0)\end{array}$ & PCI & $\begin{array}{l}\text { Rank } \\
\text { order }\end{array}$ & $\begin{array}{l}\text { Frequently } \\
\text { (3) }\end{array}$ & $\begin{array}{l}\text { Occasionally } \\
\text { (2) }\end{array}$ & $\begin{array}{l}\text { y Rarely } \\
\text { (1) }\end{array}$ & $\begin{array}{l}\text { Not at } \\
\text { all }(0)\end{array}$ & $\begin{array}{l}\text { Rank } \\
\text { order }\end{array}$ & PCI & $\begin{array}{l}\text { Frequently } \\
\text { (3) }\end{array}$ & $\begin{array}{l}\text { Occasionally } \\
(2)\end{array}$ & $\begin{array}{l}\text { Rarely } \\
(1)\end{array}$ & $\begin{array}{l}\text { Not at } \\
\text { all }(0)\end{array}$ & PCI & $\begin{array}{l}\text { Rank } \\
\text { order }\end{array}$ \\
\hline $\begin{array}{l}\text { Lack of good } \\
\text { quality inputs }\end{array}$ & 33 & 6 & 5 & 6 & $116^{b}$ & 12 & 65 & 18 & 7 & 10 & $238^{\mathrm{b}}$ & 10 & 96 & 31 & 14 & 9 & $364^{b}$ & 5 \\
\hline High price of inputs & 41 & 5 & 3 & 1 & 136 & 1 & 71 & 20 & 4 & 5 & 257 & 3 & 110 & 19 & 18 & 3 & 386 & 3 \\
\hline $\begin{array}{l}\text { Lack of transportation } \\
\text { and storage facilities }\end{array}$ & 38 & 4 & 6 & 2 & 128 & 8 & 59 & 17 & 20 & 4 & 231 & 11 & 85 & 21 & 17 & 27 & 314 & 13 \\
\hline $\begin{array}{l}\text { Lack of knowledge } \\
\text { on conservation } \\
\text { agriculture }\end{array}$ & 39 & 5 & 5 & 1 & 132 & 5 & 72 & 10 & 9 & 9 & 245 & 6 & 89 & 22 & 35 & 4 & 346 & 9 \\
\hline $\begin{array}{l}\text { Less } \\
\text { production due to } \\
\text { minimum tillage }\end{array}$ & 40 & 5 & 3 & 2 & 133 & 4 & 72 & 12 & 6 & 10 & 246 & 5 & 106 & 14 & 27 & 3 & 373 & 4 \\
\hline $\begin{array}{l}\text { Weed infestation due } \\
\text { to minimum tillage }\end{array}$ & 35 & 9 & 4 & 2 & 127 & 9 & 69 & 11 & 13 & 7 & 242 & 7 & 90 & 16 & 24 & 20 & 326 & 12 \\
\hline $\begin{array}{l}\text { Outbreak of } \\
\text { diseases }\end{array}$ & 36 & 10 & 2 & 2 & 130 & 6 & 53 & 16 & 16 & 15 & 207 & 12 & 88 & 23 & 21 & 18 & 331 & 11 \\
\hline $\begin{array}{l}\text { Crop } \\
\text { residues cannot } \\
\text { be used as fuel }\end{array}$ & 35 & 5 & 6 & 4 & 121 & 10 & 69 & 12 & 9 & 10 & 240 & 8 & 94 & 13 & 27 & 16 & 335 & 10 \\
\hline $\begin{array}{l}\text { Crop residues } \\
\text { cannot be used as } \\
\text { animal feed }\end{array}$ & 37 & 8 & 2 & 3 & 129 & 7 & 68 & 21 & 2 & 9 & 248 & 4 & 103 & 21 & 10 & 16 & 361 & 6 \\
\hline $\begin{array}{l}\text { Crop rotation being } \\
\text { a boring practice }\end{array}$ & 42 & 3 & 2 & 3 & 134 & 3 & 71 & 20 & 8 & 1 & 261 & 1 & 109 & 25 & 11 & 5 & 388 & 1 \\
\hline $\begin{array}{l}\text { Lack of } \\
\text { extension service }\end{array}$ & 31 & 7 & 6 & 6 & 113 & 13 & 57 & 11 & 11 & 21 & 204 & 13 & 99 & 22 & 16 & 13 & 357 & 7 \\
\hline $\begin{array}{l}\text { Maintenance } \\
\text { is difficult }\end{array}$ & 34 & 6 & 3 & 7 & 117 & 11 & 66 & 10 & 21 & 3 & 239 & 9 & 93 & 28 & 21 & 8 & 356 & 8 \\
\hline $\begin{array}{l}\text { Insufficient } \\
\text { institutional credit }\end{array}$ & 40 & 6 & 3 & 1 & 135 & 2 & 70 & 19 & 10 & 1 & 258 & 2 & 107 & 26 & 14 & 3 & 387 & 2 \\
\hline
\end{tabular}

a. $\mathrm{N}$ indicates number of farmers; and

b. Calculation of PCI score for the problem of lack of good quality inputs-

PCI score of focal farmers $=(33 \times 3)+(6 \times 2)+(5 \times 1)+(6 \times 0)=116$

PCI score of proximal farmers $=(65 \times 3)+(18 \times 2)+(7 \times 1)+(10 \times 0)=238$

PCI score of control farmers $=(96 \times 3)+(71 \times 2)+(14 \times 1)+(9 \times 0)=364$

PCI scores for rest of the problems were computed accordingly.

Majority of the farmers opined that the price of the production inputs were very much higher for them to meet the expenses. The PCI score of this problem was 136, 257 and 386 ranking by 1st, 2nd and 3rd in terms of focal, proximal and control farmers, respectively. Inadequate credit facility was another major problem faced by the farmers in the study areas. The credit lending process of different formal credit lending institutions was not transparent to them and as a result, they had to depend on different informal sources of credit like money lenders, relatives, friends, etc. The PCI score of this problem was calculated at 135, 258 and 387 ; which was ranked as 2 nd problem along with the statements of all the three categories of farmers (focal, proximal and control farmers). Most of the farmers stated the selection of an appropriate crop rotation as a boring practice. With the statements of focal, proximal and control farmers, the PCI score of this problem was marked as 134, 261 and 388 which was ranked as 3rd, $1 \mathrm{st}$ and 1st, respectively. Tillage requirement for crop farming in Bangladesh does not permit minimum tillage in case of most of the crops which forestalls maximum crop production. The farmers of the study areas stated this as one of the major problems. The problem was ranked as 4th, 5th and 4th in accordance with the PCI score of 133, 246 and 373 with the opinion of focal, proximal and control farmers, respectively. Being a new dimension of crop farming, the practice of conservation agriculture was innovative to the farmers. The knowledge of the farmers on this aspect was not immensely transparent. Lack of appropriate knowledge on this farming practice was a great knotty issue for the farmers. As stated by focal, proximal and control farmers, this problem was ranked as 5th, 6th and 9th by means of PCI score of 132, 245 and 346, respectively.

Other problems like lack of good quality inputs, lack of transportation and storage facilities, weed infestation due to minimum tillage, outbreak of diseases, crop residues cannot be used as fuel, crop residues cannot be used as animal feed, lack of extension service and maintenance is difficult were ranked as 12th (with PCI score 116), 8th (with PCI score 128), 9th (with PCI score 127), 6th (with PCI score 130), 10th (with PCI score 121), 7th (with PCI score 129), 13th (with PCI score 113 ) and 11th (with PCI score 117), respectively in case of focal farmers; 10th (with PCI score 238), 11th (with PCI score 231), 7th (with PCI score 242), 12th (with PCI score 207), 8th (with PCI score 240), 4th (with PCI score 248), 13th (with PCI score 204) and 9th (with PCI score 239), respectively in terms of proximal farmers; and 5th (with PCI score 364), 13th (with PCI score 314), 12th (with PCI score 326), 11th (with PCI score 331), 10th (with PCI score 335), 6th (with PCI score 361), 7th (with PCI score 357) and 8th (with PCI score 356), respectively in stare of control farmers. 


\section{Conclusion}

The study comes to an end with a conclusion that as a new resource saving farming practice, conservation agriculture was cherished highly and adopted successfully by the farmers. The study exposed that production cost of different crops was comparatively lower and return from production was moderately higher in this practice than traditional one which contributed to a noticeable increase in farmers' income. It is also revealed that majority of both focal and proximal farmers avowed about enhanced soil environmental circumstance after adopting conservation agriculture than before, while majority of control farmers stated about constant soil environmental condition. It is found from the estimates of probit model that three (minimum tillage operation, permanent organic soil cover and application of compost and vermicompost) out of six explanatory variables had significant influence on improving soil environmental quality due to conservation agriculture practice. High price of inputs, lack of institutional credit, lack of knowledge about conservation agriculture, boring practice of crop rotation, etc. were frequently faced by the farmers as problems in the study areas. Considering the findings of the study, it can be concluded that practicing conservation agriculture not only contributed to increase in farmers' income, but also protected the soil environment from effluence and damage. In real life, it can make superior use of available agricultural resources through combining limited external inputs with integrated management of soil, water and biological resources; and offer an opportunity for striking and reversing downhill resource degradation spiral, decreasing production costs and ensuring more resource-use-efficient, viable and sustainable agriculture by retaining a permanent or semi-permanent organic soil cover, crop rotation and minimum soil disturbance. Some indispensable policy guidelines have been arisen in this regard which are: Input and price intervention, scientific and technical training programmes and extension services by different government and nongovernment organizations should be properly implemented to elevate the consciousness about the importance of conservation agriculture practice on crop production among the farmers.

\section{Acknowledgement}

The authors are thankful to Ministry of Education (MoE), Government of the People's Republic of Bangladesh for funding to conduct this study.

\section{Authors' Contributions}

Md. Taj Uddin: Designed, collected and checked the analyzed data; supervised the draft manuscript and approved the final manuscript.
Aurup Ratan Dhar: Coordinated the study, collected and analyzed the data and prepared the draft manuscript.

Md. Hammadur Rahman: Supervised the work, reviewed the manuscript and contributed in data interpretation.

\section{Ethics}

This article is original and contains unpublished material. The corresponding author confirms that all of the other authors have read and approved the manuscript and no ethical issues involved.

\section{References}

Aune, J.B., 2012. Conventional, organic and conservation agriculture: Production and environmental impact. Agroecology and strategies for climate change. Sustainable Agric. Rev., 8: 149-165.

DOI: $10.1007 / 978-94-007-1905-77$

BBS, 2014. Statistical yearbook of Bangladesh, Bangladesh bureau of statistics. Statistics Division, Ministry of Planning, Government of the People's Republic of Bangladesh, Dhaka.

Clapperton, M.J., 2003. Increasing soil biodiversity through conservation agriculture: Managing the soil as a habitat. Proceedings of the 2nd World Congress on Conservation Agriculture on Producing in Harmony with Nature, (PHN' 03), Parana, Brazil.

FAO, 2007. Food and Agriculture Organization of the United Nations.

Jat, M.L., Y.S. Saharawat and R. Gupta, 2011. Conservation agriculture in cereal systems of South Asia: Nutrient management perspectives. Karnataka J. Agric. Sci., 24: 100-105.

Kafiluddin, A. and M.S. Islam, 2008. Fertilizer distribution, subsidy, marketing, promotion and agronomic use efficiency scenario in Bangladesh. Proceedings of the IFA Crossroads Asia-Pacific, (CAP' 08), Melbourne, Australia.

Lai, C., C. Chan, J. Halbrendt, L. Shariq and P. Roul et al., 2012. Comparative economic and gender, labour analysis of conservation agriculture practices in tribal villages in India. Int. Food and Agribus. Manage. Rev., 15: 73-86.

Lampkin, N.H. and S. Padel, 1994. The economics of organic farming. An international perspective. $\mathrm{Cab}$ International, Oxon, U.K.

Mazvimavi, K., P.V. Ndlovu, A. Henry and C. Murendo, 2012. Productivity and efficiency analysis of maize under conservation agriculture in Zimbabwe. Proceedings of the International Association of Agricultural Economists Conference, (AEC' 12), Foz do Iguaçu, Brazil. 
Mine, S., S. Zoubek, D.C. Watson and M. Lowe, 2014. Adoption of conservation agriculture: Economic incentives in the Iowa corn value chain.

Nguema, A., G.W. Norton, J. Alwang, D.B. Taylor and V. Barrera et al., 2013. Farm-level economic impacts of conservation agriculture in Ecuador. Exp. Agric., 49: 134-147.

Palm, C., H. Blanco-Canqui, F. DeClerck, L. Gatere and P. Grace, 2014. Conservation agriculture and ecosystem services: An overview. Agric., Ecosyst. Environ., 187: 87-105.

Parrott, N., J.E. Olesen and H. Hogh-Jensen, 2006. Certified and non-certified organic farming in the developing world. Global Development of Organic Agriculture: Challenges and Prospects. CAB International, Wallingford, Oxon.

Reicosky, D.C., 2001. Global environmental benefits of soil carbon management.

DOI: $10.1007 / 978-94-017-1143-2 \_1$
Rogers, E.M., 1995. Diffusion of Innovations. 4th Edn., The Free Press, New York.

Roy, K.C., C.A. Meisner and M.E. Haque, 2004. Status of conservation tillage for small farming of Bangladesh. Proceedings of the CIGR International Conference, (CIC' 04), Beijing, China.

Uddin, M.T. and K. Fatema, 2016. Rice crop residue management and its impact on farmers' livelihoodAn empirical study. Progressive Agric., 27: 189-199.

West, B., 2004. Sustainable conservation agriculture with No-tillage.

Willer, H., M. Yussefi, Menzler and N. Sorensen, 2008. The world of organic agriculture statistics and emerging trends 2008, main results. The World of Organic Agriculture, Bonn. 